\title{
Interaksi tropik antara hama dan parasitoid pada pertanaman sayuran: faktor pembentuk dan implikasinya terhadap keefektifan parasitoid
}

\author{
Trophic interaction between pests and parasitoids in vegetable crops: \\ determining factors and its implication to parasitoid effectiveness
}

\author{
Muhamad Nurhuda Nugraha $^{1}$, Damayanti Buchori ${ }^{{ }^{*}}$, Ali Nurmansyah ${ }^{1}$, \\ Akhmad Rizali ${ }^{2}$ \\ ${ }^{1}$ Departemen Proteksi Tanaman, Fakultas Pertanian, Institut Pertanian Bogor \\ Jalan Kamper, Kampus IPB Dramaga, Bogor 16680 \\ ${ }^{2}$ Jurusan Hama dan Penyakit Tumbuhan, Fakultas Pertanian, Universitas Brawijaya \\ Jalan Veteran, Malang 65145
}

(diterima Maret 2014, disetujui April 2014)

\begin{abstract}
ABSTRAK
Kondisi agroekosistem dapat memengaruhi keanekaragaman serta keefektifan komunitas parasitoid sebagai musuh alami serangga hama. Intensifikasi pertanian berupa budi daya tanaman monokultur dan aplikasi pestisida juga menyebabkan penurunan keanekaragaman dan kinerja parasitoid di lahan pertanian. Penelitian ini bertujuan untuk mempelajari interaksi tropik antara hama dan parasitoid pada berbagai kondisi lahan sayuran dan mempelajari faktor-faktor yang membentuk interaksi tersebut serta implikasinya terhadap keefektifan parasitoid. Penelitian dilaksanakan pada berbagai lahan sayuran di Bogor yang dikelompokkan ke dalam tiga kategori, yaitu berdasarkan pola budi daya, keanekaragaman tanaman sayuran di sekitar lahan dan perbedaan umur tanaman. Di setiap lahan sayuran, pengambilan contoh serangga dilakukan pada transek sepanjang $50 \mathrm{~m}$, yaitu dengan mengoleksi telur, larva dan pupa dari hama yang ditemukan. Sebanyak 15 spesies hama dan 15 spesies parasitoid diperoleh dari delapan spesies tanaman sayuran. Hasil analisis menunjukkan bahwa interaksi tropik antara hama dan parasitoid dipengaruhi oleh sistem budi daya, kondisi lahan (keanekaragaman tanaman disekitarnya) dan umur tanaman. Walaupun tidak signifikan, keefektifan parasitoid, yaitu berdasarkan tingkat parasitisasinya, cenderung lebih tinggi pada interaksi tropik yang terbentuk pada lahan dengan sistem budi daya organik dan kondisi pertanaman yang beranekaragam.
\end{abstract}

Kata kunci: interaksi tropik, pertanian organik, parasitoid, sayuran, umur tanaman

\begin{abstract}
The condition of agroecosystem may affect the diversity and effectiveness of parasitoid communities as natural enemies of insect pests. Agricultural intensification such as monoculture cultivation as well as application of insecticide could also cause declining to parasitoid diversity and ineffective performance of parasitoids in agricultural field. The objective of this research was to study trophic interaction between pests and parasitoids in different field of vegetable crops and to investigate the factors that determining those interactions as well as its implication on parasitoid effectiveness. Vegetable crop fields were grouped into three different categories i.e. based on the pattern of cultivation, diversity of vegetable crops around the field and age of plant. On each crop
\end{abstract}

\footnotetext{
*Penulis korespondensi: Damayanti Buchori. Departemen Proteksi Tanaman, Fakultas Pertanian, Institut Pertanian Bogor 
field, insects were sampled using $50 \mathrm{~m}$ of transect by collecting eggs, larvae and pupae of pests. In total, 15 species of pests and 15 species of parasitoids were recorded from eight species of vegetable crops. Based on the analysis, trophic interaction between pests and parasitoids were affected by cultivation system, condition of crop field (species diversity of crops in its surrounding) and age of vegetable plants. Although it was not significance, the effectiveness of parasitoids according to their parasitism level, tend to higher in trophic interaction that determined from crop field with organic systems and with diverse of crop plants.

Key words: trophic interaction, organic farming, parasitoid, vegetable crop, age of plant

\section{PENDAHULUAN}

Di Indonesia, produksi sayuran secara kuantitas dan kualitas masih terkendala dengan permasalahan hama dan tingginya residu pestisida. Penurunan rata-rata produksi sayuran segar di Indonesia dari 10 ton/ha di tahun 2010 menjadi 9,5 ton/ha di tahun 2011 (FAOSTAT 2013) disinyalir diakibatkan oleh terjadinya peningkatan serangan hama. Di sisi lain, praktek budi daya dengan penggunaan pestisida sintetik yang berlebihan pada sayuran segar dalam mengendalikan permasalahan hama, dinilai lebih banyak menimbulkan efek negatif di kalangan produsen maupun konsumen. Efek negatif ini dapat berupa kontaminasi pada bahan pangan dan pencemaran lingkungan, disamping timbulnya resistensi hama terhadap pestisida.

Pengendalian hama terpadu (PHT) sebagai suatu konsep untuk mengendalikan hama merupakan salah satu solusi untuk menghindari dampak negatif intensifikasi dalam pertanian. Penggunaan serangga musuh alami dalam penerapan PHT terbukti dapat menekan serangan organisme pengganggu tanaman (Losey \& Vaughan 2006). Secara natural, musuh alami selalu berada di lahan pertanian dan peranan yang diberikan, seperti parasitisme yang dilakukan oleh serangga parasitoid (Buchori et al. 2008), merupakan bagian dari jasa ekosistem (ecosystem services) yang menguntungkan petani (Power 2010).

Dalam upaya pelestarian serangga parasitoid pada suatu agroekosistem, pengelolaan lingkungan merupakan salah satu faktor yang dapat memengaruhi keanekaragaman serta keefektifan komunitas parasitoid pada suatu pertanaman (Plecas et al. 2014). Lahan pertanian dengan sistem budi daya tanaman yang berbeda menunjukkan pola interaksi tropik antara hama dan parasitoid yang berbeda (Lohaus et al. 2013). Kondisi lanskap pertanian dengan tipe penggunaan lahan berbeda juga memengaruhi perbedaan interaksi tropik antara hama dan parasitoid (Tylianakis et al. 2007; Plecas et al. 2014). Walaupun demikian, perbedaan interaksi tropik hama dan parasitoid antar lahan pertanian tidak selalu berhubungan dengan keefektifan parasitoid dalam mengendalikan hama (MacFadyen et al. 2009).

Penelitian ini bertujuan untuk mempelajari interaksi tropik antara hama dan parasitoid pada berbagai kondisi lahan sayuran di Bogor dan mempelajari faktor-faktor yang membentuk interaksi tersebut serta implikasinya terhadap keefektifan parasitoid. Pertanian sayuran di Bogor dikelompokkan ke dalam tiga kategori, yaitu berdasarkan pola budi daya, keanekaragaman tanaman sayuran di sekitar lahan dan perbedaan umur tanaman.

\section{BAHAN DAN METODE}

\section{Lokasi penelitian}

Lokasi penelitian merupakan area pertanaman sayuran yang terletak di Kabupaten Bogor, Jawa Barat. Area pertanaman sayuran yang dipilih mencakup berbagai ketinggian berbeda, yaitu dibawah $300 \mathrm{~m}$ dpl, 300-600 $\mathrm{m}$ dpl dan diatas $600 \mathrm{~m}$ dpl yang terletak di empat kecamatan, yaitu Cisarua, Tenjolaya, Kemang dan Ranca Bungur (Tabel 1). Sebanyak delapan jenis sayuran ditemukan pada keempat kecamatan tersebut, yaitu brokoli (Brassica oleraceae var botrytis), caisin (Brassica rapa), kubis (Brassica oleracea), pare (Momordica charantia), sawi (Brassica juncea), terong (Solanum melongenae), mentimun (Cucumis sativus), dan tomat (Solanum lycopersicum). Lahan sayuran yang terdapat pada keempat kecamatan tersebut memiliki karakter dan kondisi pertanaman berbeda meliputi pola 
budi daya, keanekaragaman tanaman sekitar dan umur tanaman (Tabel 1).

\section{Pengambilan contoh serangga}

Penelitian ini merupakan penelitian survei, yaitu tidak melakukan perancangan percobaan atau modifikasi dari lahan sayuran. Pengambilan contoh serangga dilakukan berdasarkan ketersediaan pertanaman sayuran di setiap kecamatan pada saat survei dilakukan. Lahan sayuran yang ditemukan, dicatat kondisi lahan dan sistem budi daya yang digunakan (berdasarkan informasi dari petani) untuk dapat dikelompokkan dengan lahan sayuran yang lain.

Pengambilan contoh dilakukan dari bulan Agustus hingga Oktober 2012, dengan frekuensi pengambilan per lahan di setiap kecamatan sebanyak satu kali untuk setiap bulannya. Di setiap lahan sayuran yang ditemukan (luas minimal $1000 \mathrm{~m}^{2}$ ), pengambilan contoh serangga dilakukan menggunakan metode transek sepanjang $50 \mathrm{~m}$ dengan lama pengamatan 30 menit. Parasitoid dikoleksi dengan mengambil hama atau inang pada berbagai stadia (meliputi telur, larva dan pupa) yang ditemukan pada setiap langkah. Hama yang diperoleh selanjutnya dibawa ke laboratorium untuk dipelihara dan dihitung kejadian parasitisasinya.

\section{Identifikasi hama dan parasitoid}

Identifikasi serangga hama dan parasitoid(Ordo Hymenoptera dan Diptera) yang muncul dilakukan hingga tingkat famili dengan menggunakan buku The Pest of Crops in Indonesia (Kalshoven 1981), Hymenoptera of the World (Goutlet \& Huber 1993) dan Manual of Nearctic Diptera (McAlpine 1987). Beberapa parasitoid dilakukan identifikasi hingga tingkat spesies dengan bantuan taksonomis di Museum Zoologi, LIPI, Bogor.

\section{Analisis data}

Oleh karena penelitian survei, jumlah unit pengambilan contoh (transek) berbeda untuk setiap jenis sayuran disesuaikan dengan ketersediaan di lapangan (Tabel 1). Analisis data dalam hal ini hanya dilakukan pada tanaman-tanaman yang

Tabel 1. Lokasi penelitian dan jenis sayuran yang ditemukan di empat kecamatan di Bogor. Kode untuk sistem pertanian, Or: Organik, Ko: Konvensional, Mo: Monokultur, Ol: Oligokultur, P1: Polikultur (5-8 spesies tanaman sayuran), P2: Polikultur (9-15 spesies tanaman sayuran)

\begin{tabular}{|c|c|c|c|c|c|}
\hline $\begin{array}{l}\text { Ketinggian } \\
(\mathrm{m} \mathrm{dpl})\end{array}$ & Desa, Kecamatan & Komoditas & Kode lokasi & $\begin{array}{l}\text { Jumlah } \\
\text { transek }\end{array}$ & $\begin{array}{c}\text { Sistem } \\
\text { pertanian }\end{array}$ \\
\hline \multirow[t]{6}{*}{$<300$} & Bantarsari, Rancabungur & Terong & BS1 & 2 & Ko,Mo \\
\hline & & & BS2 & 3 & Ko,Mo \\
\hline & & & BS3 & 3 & Кo,Mo \\
\hline & & Pare & BS1 & 1 & Ko,Mo \\
\hline & & Mentimun & BS4 & 1 & Кo,Мо \\
\hline & Bojong, Kemang & Terong & BJ1 & 3 & Ko,Mo \\
\hline \multirow[t]{4}{*}{$300-600$} & Situ Daun, Tenjolaya & Caisin & SD1 & 3 & Ko,Mo \\
\hline & & & SD2 & 3 & Ko,Mo \\
\hline & & & SD3 & 3 & Ko,Mo \\
\hline & & & SD4 & 1 & Ko,Mo \\
\hline \multirow[t]{10}{*}{$>600$} & Tugu Selatan, Cisarua & Kubis & TS1 & 2 & Or,P1 \\
\hline & & & TS2 & 1 & $\mathrm{Ko}, \mathrm{Ol}$ \\
\hline & & & TS5 & 2 & Or,P2 \\
\hline & & & TS6 & 3 & Or,P2 \\
\hline & & & TS7 & 4 & Or,P2 \\
\hline & & Caisin & TS1 & 1 & Or,P1 \\
\hline & & & TS3 & 3 & Or,P1 \\
\hline & & Sawi & TS2 & 1 & $\mathrm{Ko}, \mathrm{Ol}$ \\
\hline & & Brokoli & TS5 & 1 & Or,P2 \\
\hline & & Tomat & TS4 & 1 & $\mathrm{Ko}, \mathrm{Ol}$ \\
\hline
\end{tabular}


memiliki unit pengambilan contoh yang cukup, yaitu caisin, kubis dan terong. Meskipun jumlah unit samplingnya berbeda, di dalam melakukan analisis tetap menggunakan keseluruhan data. Berdasarkan pengelompokan yang dilakukan, ditemukan bahwa tanaman caisin mewakili sistem budi daya yang berbeda, yaitu konvensional dan organik. Tanaman kubis mewakili kondisi habitat yang berbeda, yaitu beragam (keanekaragaman tanaman pertanian disekitar lahan 9-15 jenis) dan kurang beragam (keanekaragaman tanaman pertanian disekitar lahan 5-8 jenis), sedangkan terong dapat mewakili perbedaan umur, yaitu 3, 4 dan 5 bulan. Hal tersebut dimungkinkan karena tanaman terong selalu tersedia pada lahan yang sama selama tiga bulan pengambilan contoh.

Persentase serangan hama dan parasitisasi parasitoid dihitung dengan persamaan yang dimodifikasi dari Hamid et al. (2003) untuk kemudian ditampilkan dalam bentuk box-plot. Pengaruh sistem pertanian terhadap tingkat serangan hama dan parasitisasi parasitoid pada pertanaman caisin, kubis dan terong dianalisis dengan menggunakan analisis ragam (ANOVA). Interaksi tropik antara hama dan parasitoid antar lahan digambarkan dalam bentuk grafik interaksi tropik (Tylianakis et al. 2007). Keseluruhan analisis dilakukan dengan perangkat lunak $R$ statistics (R Core Team 2014).

\section{HASIL}

\section{Keanekaragaman hama dan parasitoid pada pertanaman sayuran di Bogor}

Berdasarkan hasil survei yang dilakukan, ditemukan 15 spesies hama dan 15 spesies parasitoid dari delapan jenis tanaman sayuran yang diobservasi (Gambar 1). Hampir seluruh tanaman sayuran yang disurvei diserang hama kecuali tanaman mentimun pada saat survei yang dilakukan tidak ditemukan hama mentimun. Jenis hama terbanyak ditemukan pada sayuran kubis ( 9 spesies) dan caisin (8 spesies). Pada pertanaman kubis, caisin dan brokoli, jenis hama yang selalu ditemukan adalah Crocidolomia pavonana dan Plutella xylostella.

Parasitoid yang memarasit $P$. xylostella pada tanaman kubis lebih banyak (5 spesies) 106 dibandingkan dengan pada tanaman caisin (4 spesies) dan brokoli (1 spesies), sedangkan parasitoid yang memarasit $C$. pavonana lebih banyak ditemukan di tanaman caisin (4 spesies) dibandingkan dengan kubis (2 spesies) dan brokoli (tidak ditemukan) (Gambar 1). Parasitoid Diadegma semiclausum dan Tachinidae-1 banyak ditemukan pada tanaman caisin dan kubis, sedangkan parasitoid Pediobius foveolatus dan Trichogramma sp hanya ditemukan pada tanaman terong (Gambar 1).

\section{Interaksi tropik hama dan parasitoid: faktor pembentuk dan implikasinya terhadap kinerja parasitoid}

Untuk memelajari faktor pembentuk interaksi tropik hama dan parasitoid dan implikasinya terhadap kinerja parasitoid, analisis difokuskan pada pengaruh sistem budi daya, kondisi habitat sekitar lahan sayuran dan perbedaan umur tanaman sayuran. Melalui studi kasus pada tanaman caisin, hasil analisis pengaruh sistem budi daya menunjukkan bahwa interaksi tropik hama dan parasitoid terlihat berbeda antara sistem budi daya konvensional dan organik. Jenis parasitoid yang memarasit hama di sistem konvensional seluruhnya berbeda dengan sistem organik (Gambar 2). Sistem budi daya juga memengaruhi tingkat serangan hama, yaitu lebih tinggi pada sistem organik dibandingkan dengan konvensional $\left(\mathrm{F}_{1,12}=53,44, \mathrm{P}<0,001, \mathrm{CV}=39,74\right)$. Meskipun hasil analisis tidak berbeda nyata $\left(\mathrm{F}_{1,12}=\right.$ 0,018, $\mathrm{P}=0,897, \mathrm{CV}=93,28)$, berdasarkan median menunjukkan bahwa tingkat parasitisasi lebih tinggi pada sistem organik dibandingkan dengan onvensional (Gambar 3).

Hasil analisis pengaruh kondisi habitat (studi kasus pada tanaman kubis) menunjukkan bahwa interaksi tropik antara hama dan parasitoid pada lahan dengan kondisi habitat beragam berbeda dengan habitat kurang beragam (Gambar 4). Jenis hama yang menyerang lahan dengan kondisi habitat beragam lebih banyak dan berbeda spesies dibandingkan dengan hama yang menyerang lahan dengan kondisi habitat kurang beragam (Gambar 4). Jenis parasitoid yang ditemukan juga berbeda dan lebih banyak pada lahan dengan kondisi habitat beragam. Empat spesies parasitoid ditemukan di lahan dengan kondisi habitat beragam, sedangkan 


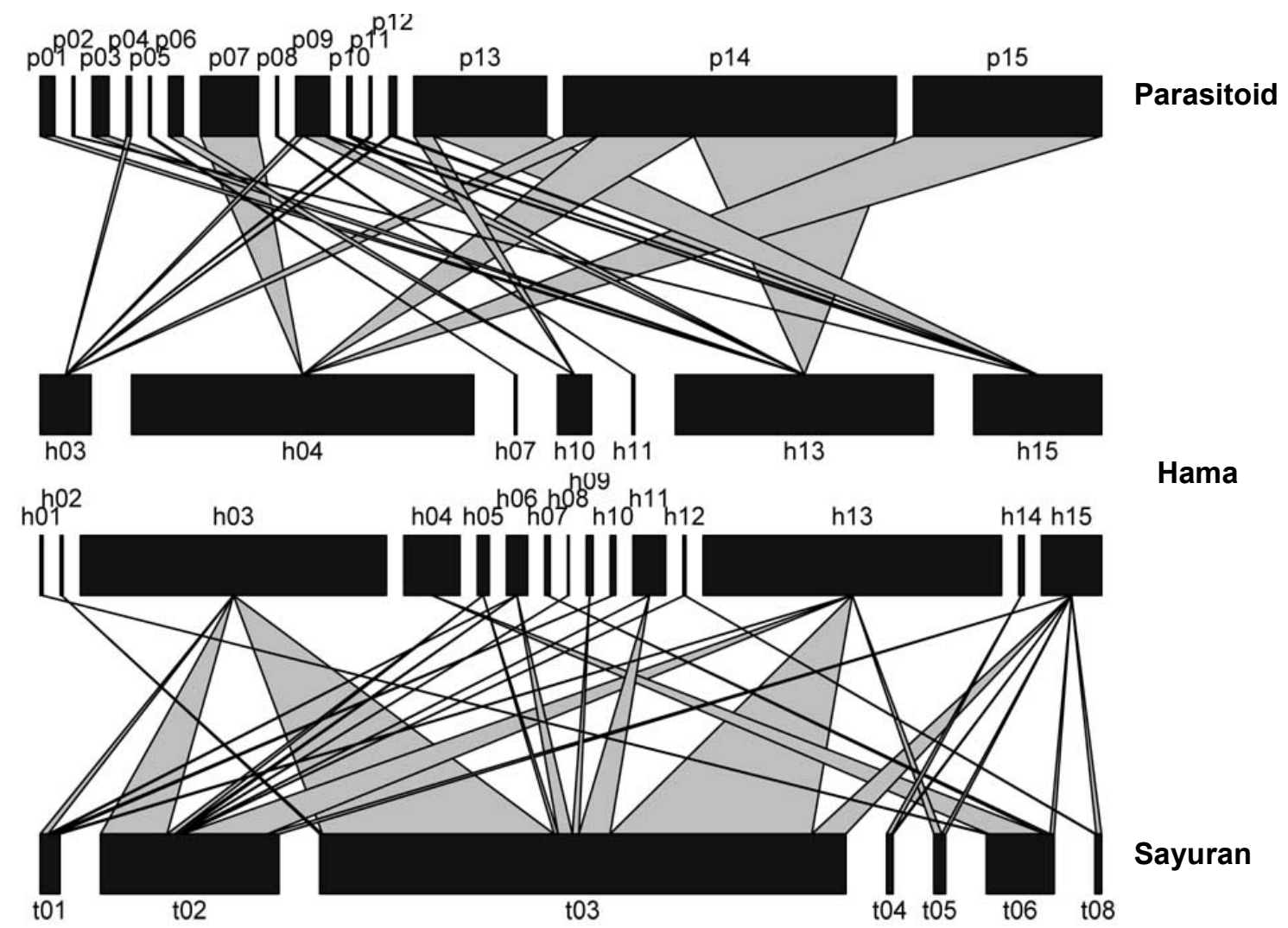

Sayuran: $\mathrm{t} 01=$ brokoli, $\mathrm{t} 02=$ caisin, $\mathrm{t} 03=$ kubis, $\mathrm{t} 04=$ pare, $\mathrm{t} 05=$ sawi, t06=terong, $\mathrm{t} 07=$ mentimun, $\mathrm{t} 08=$ tomat

Hama: h01=Acherontia sp., h02=Agrotis sp, h03=Crocidolomia pavonana, h04=Epilachna sp, h05=Eupterote sp. h06=Hellula sp., h07=Mahasena corbetti, h08=Noctuidae-1, h09=Orgyia sp., h10=Phyllotreta vittata, h11=Pieris brassicae, h12=Plusia $\mathrm{sp} ., \mathrm{h} 13=$ Plutella $x y$ lostella, h14=Rodolia $\mathrm{sp} ., \mathrm{h} 15=$ Spodoptera litura

Parasitoid: p01=Apanteles sp.1, p02=Bracon sp., p03=Diadegma semiclausum, p04=Eriborus sp.3, p05=Goryphus sp., p06=Idris sp, p07=Pediobius foveolatus, p08=Pteromalus puparum, p09=Tachinidae-1, p10=Tachinidae-2, p11=Tachinidae-3, p12=Tachinidae-4, p13=Telenomus sp., p14=Tetrastichus howardi, p15=Trichogramma spp.

Gambar 1. Interaksi tropik antara parasitoid dan hama/herbivor (atas), serta hama dan tanaman sayuran (bawah) dari keseluruhan tanaman sayuran di areal sampling, Kabupaten Bogor.

(a)

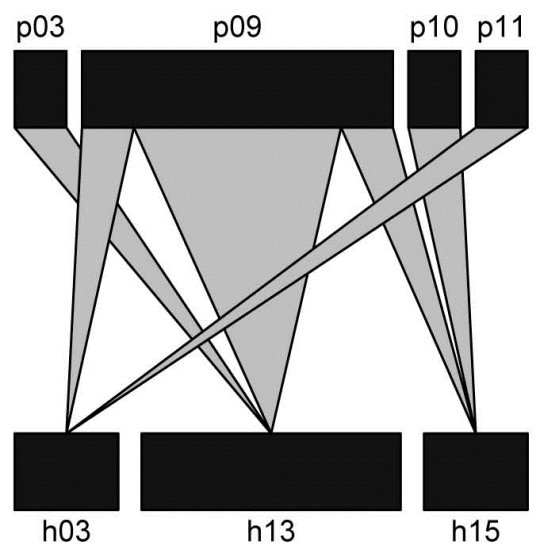

(b)

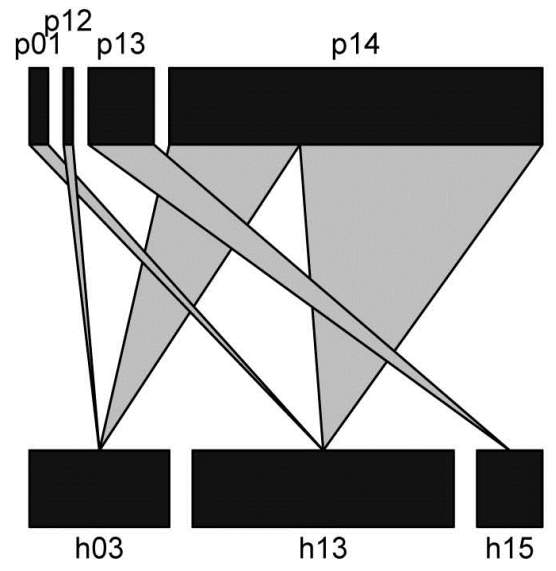

Gambar 2. Interaksi tropik hama dan parasitoid pada pertanaman caisin dengan sistem budi daya (a) organik dan (b) konvensional. Kode spesies sama dengan kode spesies yang terdapat dalam Gambar 1. 

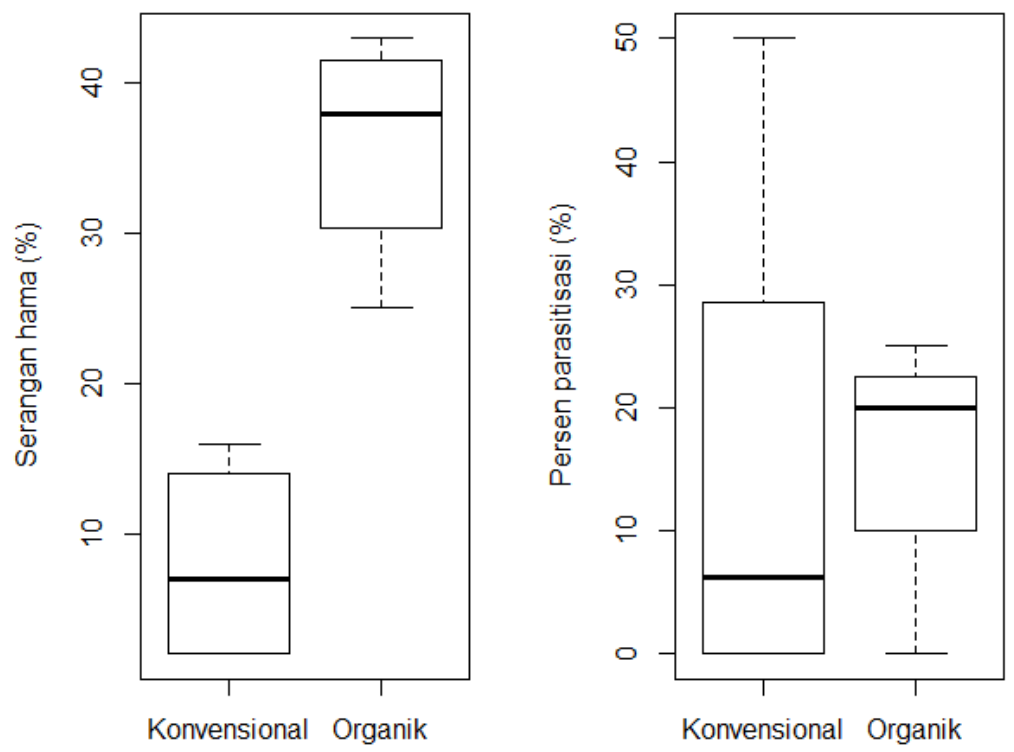

Gambar 3. Persentase serangan hama (kiri) dan tingkat parasitisasinya (kanan) pada pertanaman caisin di Bogor. Sistem budi daya dikelompokkan ke dalam konvensional $(n=0)$ dan organik $(n=4)$.

(a)

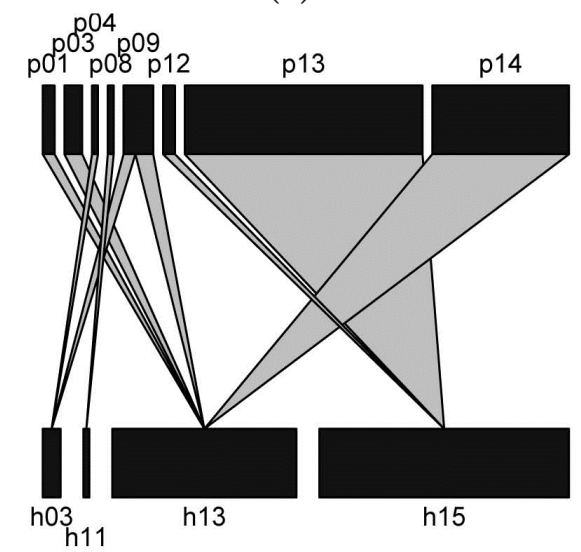

(b)

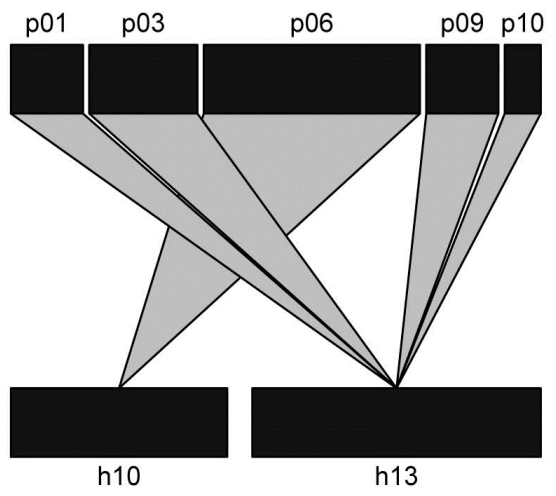

Gambar 4. Interaksi tropik hama dan parasitoid pada pertanaman kubis dengan kondisi habitat (a) beragam dan (b) kurang beragam. Kode spesies sama dengan kode spesies yang terdapat dalam Gambar 1.

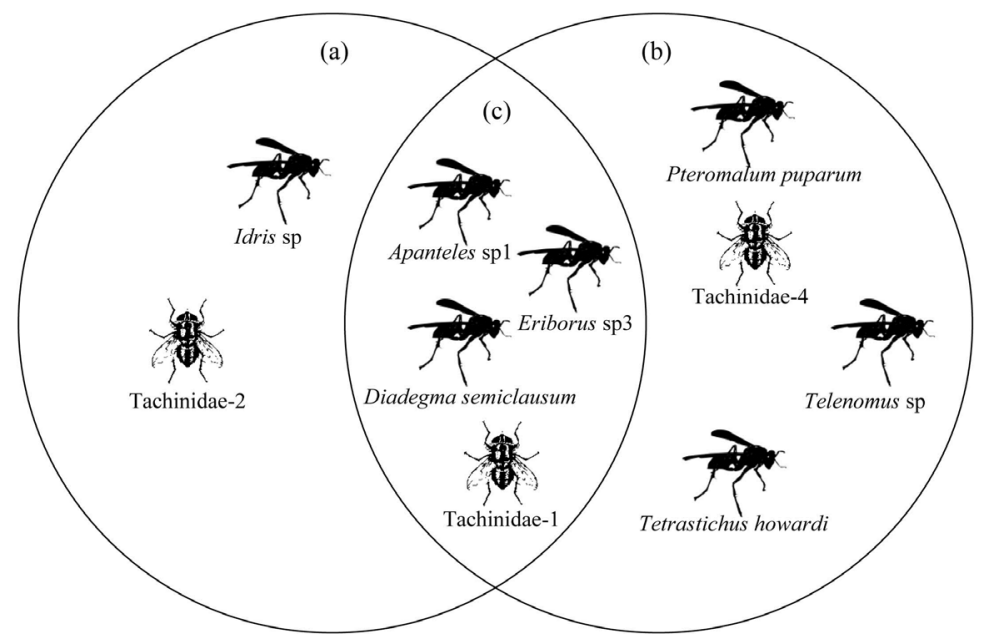

Gambar 5. Keanekaragaman parasitoid yang ditemukan pada pertanaman kubis dengan keanekaragaman jenis tanaman disekitar lahan (a) 5-8 spesies, (b) 9-15 spesies dan (c) irisan diantara keduanya. 
empat spesies yang lain ditemukan di kedua kondisi habitat (Gambar 5). Berdasarkan hasil analisis, tidak terdapat perbedaan tingkat serangan hama antara kondisi habitat beragam dan kurang beragam $\left(\mathrm{F}_{1,10}=0,047, \mathrm{P}=0,8319, \mathrm{CV}=10,08\right)$. Demikian juga tingkat parasitisasi parasitoid juga tidak menunjukkan perbedaan antara kedua kondisi habitat $\left(\mathrm{F}_{1,10}=1,681, \mathrm{P}=0,224, \mathrm{CV}=65,65\right)$, meskipun berdasarkan nilai median menunjukkan bahwa tingkat parasitisasi lebih tinggi pada kondisi habitat kurang beragam (Gambar 6).

Melalui studi kasus pada tanaman terong, umur tanaman juga memengaruhi hubungan tropik antara hama dan parasitoid (Gambar 7). Terjadi perubahan komposisi hama dan parasitoid antara umur tanaman terong 3 bulan dan 4 bulan, kemudian terjadi penurunan spesies hama dan parasitoid pada umur 5 bulan. Meskipun tidak terdapat perbedaan tingkat serangan hama pada umur tanaman berbeda $\left(\mathrm{F}_{2,8}=0,016, \mathrm{P}=0,983\right.$, $\mathrm{CV}=41,08)$, pada umur 4 bulan cenderung lebih tinggi tingkat serangan hamanya berdasarkan nilai median (Gambar 8). Umur tanaman terong juga tidak memengaruhi tingkat parasitisasi parasitoid $\left(\mathrm{F}_{2,8}=0,323, \mathrm{P}=0,732, \mathrm{CV}=103,78\right)$, walaupun demikian berdasarkan nilai median menunjukkan bahwa semakin bertambah umur maka tingkat parasitisasi semakin menurun (Gambar 8).

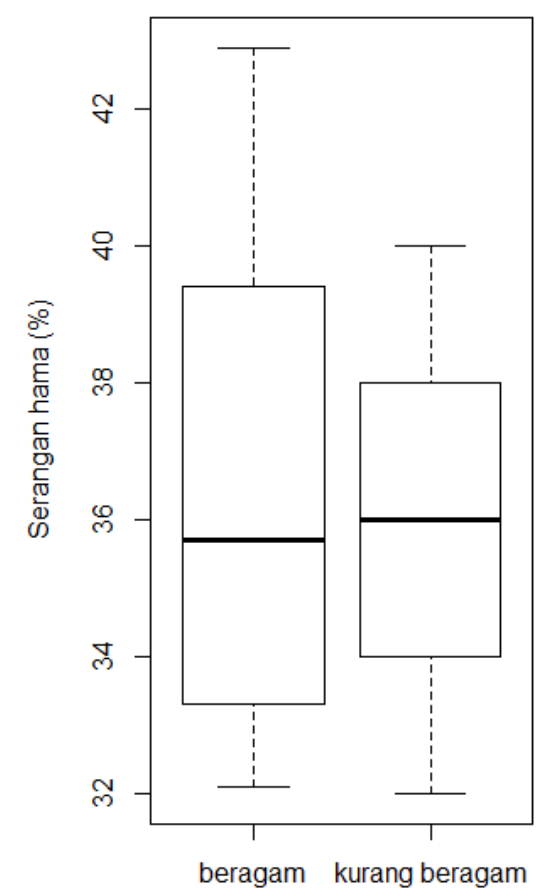

\section{PEMBAHASAN}

Keberadaan parasitoid pada suatu lahan pertanian dipengaruhi oleh kondisi habitat disekitar lahan pertanian tersebut. Keanekaragaman jenis parasitoid ditemukan lebih tinggi pada lahan pertanian yang dekat dengan habitat pepohonan (Herlina et al. 2011) atau hutan (Hamid et al. 2003). Kondisi habitat sekitar lahan pertanian juga dapat memengaruhi interaksi tropik antara hama dan parasitoid (Tylianakis et al. 2007). Lahan sayuran di Bogor dengan kondisi habitat beragam memiliki interaksi tropik yang berbeda dengan kondisi habitat yang kurang beragam. Hal tersebut berhubungan erat dengan keanekaragaman hama yang lebih banyak ditemukan pada kondisi habitat yang beragam. Selain itu, senyawa kimia volatil yang dikeluarkan oleh spesies tanaman tertentu di sekitar pertanaman juga dapat memengaruhi perilaku parasitoid dalam menemukan inangnya (Thaler 1999; Stireman 2002; Girling et al. 2010). Oleh karena itu, keanekaragaman parasitoid maupun interaksi tropik hama dan parasitoid yang terbentuk menjadi berbeda antara kondisi habitat yang beragam dan kurang beragam.

Sistem budi daya pertanian juga dapat memengaruhi keberadaan parasitoid pada suatu lahan sayuran. Sistem budi daya sayuran secara

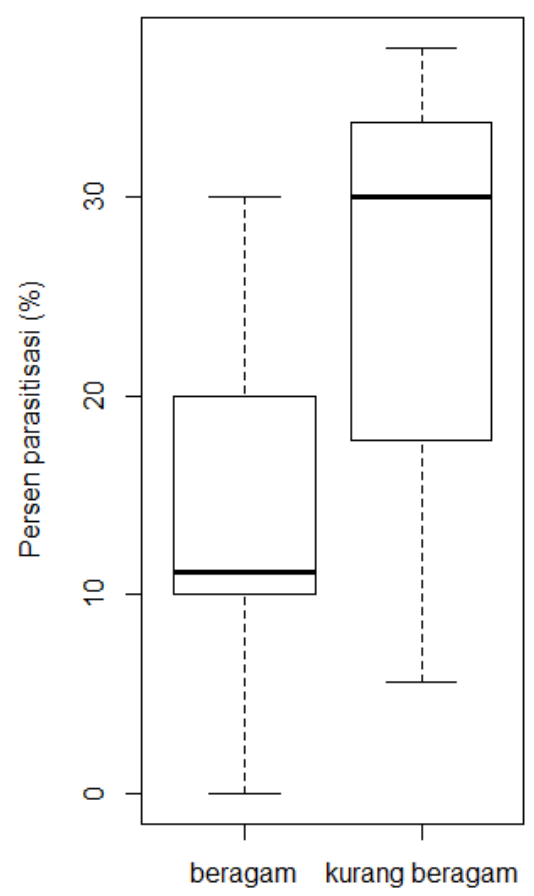

Gambar 6. Persentase serangan hama (kiri) dan tingkat parasitisasinya (kanan) pada pertanaman kubis di Bogor. Keanekaragaman jenis tanaman disekitar pertanaman kubis dikelompokkan ke dalam $5-8$ spesies ( $n=3)$ dan $9-15$ spesies $(n=9)$. 
(a)

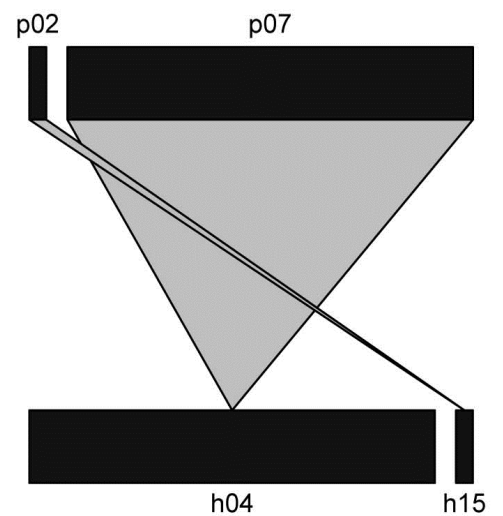

(b)

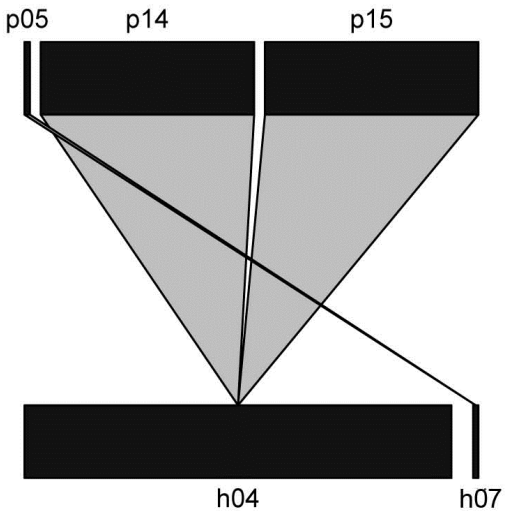

(b)

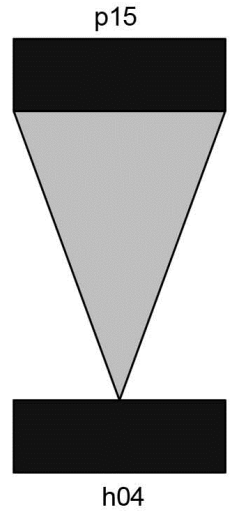

Gambar 7. Interaksi tropik hama dan parasitoid pada pertanaman terong pada berbagai umur. a: 3 bulan; b: 4 bulan; dan c: 5 bulan.
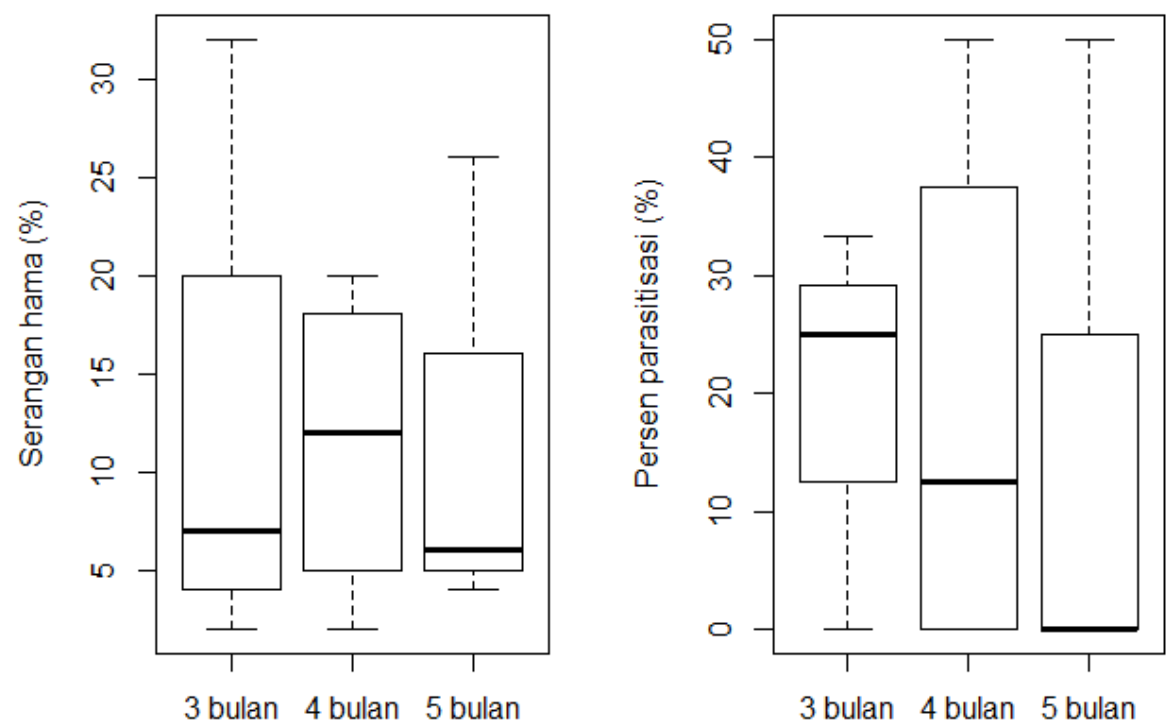

Gambar 8. Persentase serangan hama (kiri) dan tingkat parasitisasinya (kanan) pada pertanaman terong di Bogor. Umur tanaman terong dikelompokkan ke dalam 3 bulan $(n=4), 4$ bulan $(n=4)$ dan 5 spesies $(n=3)$

organik akan mendukung keberadaan parasitoid yang berperan penting dalam menurunkan populasi hama dan menjaga kestabilan agroekosistem (Bengtsson et al. 2005). Aplikasi insektisida yang umum dilakukan pada sistem budi daya konvensional, disamping mematikan hama juga berdampak negatif terhadap parasitoid (Rusch et al. 2010). Aplikasi insektisida menyebabkan penurunan keefektifan parasitoid dalam mengendalikan hama, seperti terjadinya perubahan perilaku parasitoid dalam menemukan inangnya dan penurunan kemampuan parasitisasi (Salerno et al. 2002). Sebagai akibatnya, interaksi tropik antara hama dan parasitoid yang terbentuk menjadi berbeda dibandingkan dengan sistem budi daya organik (Lohaus et al. 2013).
Umur tanaman sangat berhubungan dengan kelimpahan dan jenis hama yang ditemukan pada lahan sayuran, termasuk interaksi tropik antara hama dan parasitoid yang terbentuk. Dengan bertambahnya umur tanaman, komunitas organisme yang ada pada suatu pertanaman cenderung lebih stabil dengan ditunjukkan tingkat parasitisasi yang lebih tinggi. Selain itu perubahan fenologi tanaman sebagai konsekuensi dari peningkatan umur tanaman, juga menyebabkan terjadinya perubahan preferensi parasitoid dalam memarasit inangnya (Smyth et al. 2003). Walaupun demikian, umur tanaman dan tingkat parasitisasi parasitoid tidak menunjukkan hubungan linier. Hasil penelitian yang diperoleh menunjukkan 
bahwa pada umur tanaman sayuran tertentu, tingkat parasitisasi terjadi penurunan.

Interaksi tropik antara hama dan parasitoid yang terbentuk pada lahan sayuran di Bogor dipengaruhi oleh berbagai faktor yang masingmasing memiliki mekanisme yang sangat kompleks. Setiap faktor memiliki peranan sendiri-sendiri ataupun bersama-sama dalam membentuk pola interaksi sebagai pengaruh dari perbedaan karakteristik agroekosistem antar lokasi penelitian. Setiap lokasi memiliki karakteristik agroekosistem yang khas sebagai hasil dari perbedaan iklim, topografi tanah, kondisi ekonomi dan sejarah penggunan lahan yang memengaruhinya (Letourneau \& Altieri 1999). Oleh karena itu, pengelolaan agroekosistem dalam upaya meningkatkan keefektifan parasitoid perlu memperhatikan karakteristik dari agroekosistem tersebut khususnya yang berkaitan dengan pengelolaan kawasan dan teknologi serta cara budi daya yang digunakan (Mattson et al. 1984; Altieri 1989).

\section{KESIMPULAN}

Interaksi tropik hama dan parasitoid pada lahan sayuran di Bogor dipengaruhi oleh sistem budi daya, kondisi habitat (keanekaragaman tanaman pertanian disekitar lahan) dan umur tanaman sayuran. Interaksi yang terbentuk tidak memengaruhi keefektifan parasioid dalam menekan populasi hama. Walaupun demikian, berdasarkan analisis menunjukkan bahwa terdapat kecenderungan interaksi tropik yang terbentuk pada pertanaman sayuran dengan sistem budi daya organik dan dengan kondisi habitat beragam memiliki tingkat parasitisasi lebih tinggi.

\section{DAFTAR PUSTAKA}

Altieri MA. 1989. Agroecology: a new research and development paradigm for word agriculture. Agriculture, Ecosystems, and Environment. 27:37-46.

Bengtsson J, Anhstrom J, Weibull AC. 2005. The effects of organic agriculture on biodiversity and abundance: a meta-analysis. Journal of Applied Ecology 42:261-269.
Buchori D, Sahari B, Nurindah. 2008. Conservation of agroecosystem through utilization of parasitoid diversity: lesson for promoting sustainable agriculture and ecosystem health. HAYATI Journal of Biosciences 15:165-172.

FAOSTAT. 2013. FAO statistical yearbook 2013. UN Food \& Agriculture Organisation.

Girling RD, Stewart-Jones A, Dherbecourt J, Staley JT, Wright DJ, Poppy GM. 2010. Parasitoids select plants more heavily infested with their caterpillar hosts: a new approach to aid interpretation of plant headspace volatiles. Proceedings of Royal Society B 2725:1-8.

Goutlet H, Huber JT. 1993. Hymenoptera of the World: an Identification Guide to Families. Ottawa: Centre for Land and Biological Resources Research.

Hamid H, Buchori D, Triwidodo H. 2003. Keanekaragaman parasitoid dan parasitisasinya pada pertanaman padi di kawasan Taman Nasional Gunung Halimun. HAYATI Journal of Biosciences 10:85-90.

Herlina N, Rizali A, Moerfiah, Sahari B, Buchori D. 2011. Effect of rice field surrounding habitat and age of rice plant on the diversity of Parasitic Hymenoptera. Jurnal Entomologi Indonesia 8:17-26.

Kalshoven LGE. 1981. The Pests of Crops in Indonesia. Jakarta: Ichtiar Baru.

Letourneau DK, Altieri MA. 1999. Biology of parasitic Hymenoptera. In: Bellows TS, Fisher TW (Eds.), Handbook of Biological Control: Principles and Applications of Biological Control. San Diego: Academic Press.

Lohaus K, Vidal S, Theis C. 2013. Farming practices change food web structures in cereal aphid-parasitoid-hyperparasitoid communities. Oecologia 171:249-259.

Losey JE, Vaughan M. 2006. The economic value of ecological services provided by insects. Bioscience 56:311-323.

MacFadyen S, Gibson R, Polaszek A, Morris RJ, Craze PG, Planque R, Symondson WOC, Memmott J. 2009. Do differences in food web structure between organic and conventional farms affect the ecosystem service of pest control? Ecology Letters 12:229-238.

Mattson PC, Altieri MA, Gagne WC. 1984. Modification of small farmer practice for better pest management. Annual Review of Entomology 29:303-402.

McAlpine JF. 1987. Manual of Nearctic Diptera Volume 2. Ottawa: Research Branch Agriculture Canada. 
Plecas M, Gagic V, Jankovic M, Petrovic-Obradovic O, Kavallieratos NG, Tomanovic Z, Thies C, Tscharntke T, Cetkovic A. 2014. Landscape composition and configuration influence cerealaphid-parasitoid-hyperparasitoid interactions and biological controldifferentially across years. Agriculture, Ecosystems and Environment 183:1-10.

Power AG. 2010. Ecosystem services and agriculture: tradeoffs and synergies. Philosophical Transactions of the Royal Society of London, Series B: Biological Sciences 365:2959-2971.

R Core Team. 2014. R: A Language and Environment for Statistical Computing. Vienna: R Foundation for Statistical Computing.

Rusch A, Valantin-Morison M, Sarthou J-P, RogerEstrade J. 2010. Biological Control of Insect Pests in Agroecosystems: Effects of Crop Management, Farming Systems, and Seminatural Habitats at the Landscape Scale: A Review. In: Donald LS (Ed.), Advances in Agronomy. pp. 219-259: Academic Press.
Salerno G, Colazza S, Conti E. 2002. Sub-lethal effects of deltamethrin on walking behaviour and response to host kairomone of the egg parasitoid Trissolcus basalis. Pest Management Science 58:663-668.

Smyth RR, Hoffmann MP, Shelton AM. 2003. Effects of host plant phenology on oviposition preference of Crocidolomia pavonana (Lepidoptera: Pyralidae). Environmental Entomology 32:756764.

Stireman JO. 2002. Host location and selection cues in a generalist tachinid parasitoid. Entomologia Experimentalis et Applicata 103:23-34.

Thaler JS. 1999. Jasmonate-inducible plant defences cause increased parasitism of herbivores. Nature 399:696-688.

Tylianakis JM, Tscharntke T, Lewis OT. 2007. Habitat modification alters the structure of tropical hostparasitoid food webs. Nature 445:202-205. 